\title{
KOMPENSASI DAN PENGHARGAAN SEBAGAI INTERVENING HUBUNGAN ANTARA PENERAPAN DISIPLIN DAN KINERJA PEGAWAI DI BKKBN PROVINSI JAWA TIMUR
}

\author{
Siti Rokhmi Fuadati' ${ }^{1)}$, Nuzulianti Rahayu ${ }^{2)}$ \& Hening Widi Oetomo ${ }^{3)}$ \\ siti_rokhmi@yahoo.co.id \\ 1) \& ${ }^{3)}$ Sekolah Tinggi Ilmu Ekonomi Indonesia (STIESIA) Surabaya \\ 2) BKKBN Jawa Timur
}

\begin{abstract}
The aim of the research is to study and analyze performances of East Java BKKBN's officers by describing a conceptual framework about both direct and indirect impacts of Disciplinary Applying variables, Compensating, and Rewarding and Performances. In this research, performances levels directly influenced by Disciplinary Applying and indirect by bith disciplinary applying on performances through compensating and rewarding to East Java BKKBN's officers. Sample of the research was proportionally taken using cluster system and served as respondent were East Java BKKBN's officers as much 82 people. Data types used in the study were primary and secondary data with the questionnaire division.Based on the performed hypothetical cross-variable causality test using Path Analysis, obtained: Disciplinary Applying variables have a direct impact on performances with value or standardized coeficient of 0.209. Disciplinary Applying variables have an indirect impact on performances through compensating with value or standardized coeficient of 0.066. Disciplinary Applying variables have an indirect impact on performances through rewarding with value or standardized coeficient of 0.323 . Disciplinary Applying variables have an indirect impact on performances through compensating and rewarding with value or standardized coeficient of 0.431. More researches are required to develop the goal of this study in the future by observing performance improvement among the officers through Disciplinary Applying and Compensating as well as Rewarding but with different indicator selection than those in the study or adding more variables as well as expanding population thereby such as an analytical framework was obtained.
\end{abstract}

Key word: disciplinary applying, compensating, rewarding and performance.

\section{PENDAHULUAN}

Rao (1998) menyatakan bahwa untuk mengembangkan kemampuan yang dimiliki oleh seorang karyawan, maka minat mengembangkan diri harus datang dari karyawan itu 
sendiri, misalnya dengan meningkatkan disiplin diri dan mengetahui tingkat kepuasan kerja yang diinginkan didalam mengerjakan suatu pekerjaan. Disiplin tanpa rasa tanggung jawab, tanpa memahami tujuan, tanpa motivasi maka lambat laun disiplin itu akan mengalami kehancuran dari dalam diri sendiri. Sehingga disiplin tehadap suatu ketentuan, terhadap perundang-undangan, terhadap suatu kebijakan, perlu dikaji dan dilandasi untuk mencapai tujuan yang telah disepakati bersama

Simamora (2003), menyatakan bahwa kinerja merupakan suatu pencapaian persyaratan pekerjaan tertentu yang akhirnya secara langsung dapat tercermin dari keluaran non fisik, oleh sebab itu, upaya untuk meningkatkan kualitas sumber daya manusia yang baik dan sesuai dengan harapan organisasi tentunya dapat dilakukan melalui penerapan disiplin, pemberian kompensasi dan penghargaan dalam meningkatkan kinerja sumber daya manusia.

Ciri individual dan ciri lingkungan yang membentuk kinerja, oleh sebab itu, salah satu faktor penting yang mempengaruhi kinerja di dalam organisasi adalah sumber daya manusia atau pegawai, jika sumber daya manusia pegawai itu berkualitas baik maka akan sangat membantu kelancaran di dalam proses pekerjaan untuk menuju tujuan yang diharapkan oleh organisasi. Upaya pengintegrasian kebutuhan personel atau pegawai yang berkualitas untuk di berbagai bidang yang ada di dalam organisasi maupun di luar organisasi tentunya dilakukan melalui pendidikan dan pelatihan, saat ini pengakuan terhadap sumber daya manusia-pegawai senantiasa mempunyai kedudukan yang semakin penting di dalam organisasi tanpa sumber daya manusia yang berorientasi kerja maka tujuan organisasi tidak akan dapat terpenuhi, oleh sebab itu manusia pegawai merupakan sebagai anggota organisasi yang diharapkan dapat melakukan proses pekerjaan dan mampu mendukung kebijakan organisasi dalam mencapai tujuan yang diharapkan.

Tuntutan akan kemampuan dan tanggungjawab setiap pribadi karyawan yang ada di dalam organisasi menjadi semakin tinggi. Para karyawan tidak hanya sekedar menyelesaikan pekerjaan karena menerima imbalan yang cukup, akan tetapi seseorang/karyawan harus bekerja secara optimal untuk dapat menghasilkan kinerja yang baik tentunya sangat dipengaruhi oleh kepribadian yang berbeda-beda, misalnya sifat, sikap, nilai-nilai, keinginan dan minat. Fenomena-fenomena seperti itu juga terjadi di lingkungan BKKBN Provinsi Jawa Timur sejak tahun 2008 hingga tahun 2009 para pegawai/karyawan yang melakukan aktivitasnya belum menunjukkan tanda-tanda peningkatan terhadap kinerja bawahannya yang baik. Hasil ini dapat dilihat dari tingkat pencapaian kinerja standar rata-ratanya dalam periode dua tahun sebesar 73,5 poin, hal ini tentunya masih berhubungan dengan tingkat kehadiran pegawai di lingkungan BKKBN Provinsi Jawa Timur. Untuk memperjelas fenomena-fenomena yang terjadi di lingkungan BKKBN Provinsi Jawa Timur menunjukkan hasil tingkat kehadiran pegawai, karena turunnya disiplin dan kinerja salah satu indikasinya adalah tingkat absensi yang naik/tinggi (Brannick, 1995), yang dapat dilihat dalam tabel 1 sebagai berikut: 
Tabel 1

Distribusi Tingkat Kehadiran Pegawai BKKBN Provinsi Jawa Timur Tahun 2009 (dalam prosentase)

\begin{tabular}{|c|c|c|c|c|c|c|c|}
\hline \multirow{2}{*}{$\begin{array}{l}\text { Tujuan } \\
\text { Jangka } \\
\text { Pendek }\end{array}$} & \multirow{2}{*}{$\begin{array}{c}\text { Identifikasi } \\
\text { Perolehan } \\
\text { Kinerja } \\
\text { Pegawai }\end{array}$} & \multirow[b]{2}{*}{ Satuan } & \multirow{2}{*}{$\begin{array}{c}\text { Rata-Rata } \\
\text { Kehadiran } \\
\quad(\%)\end{array}$} & \multicolumn{4}{|c|}{$\begin{array}{c}\text { Tingkat Kinerja Yang } \\
\text { Diinginkan }\end{array}$} \\
\hline & & & & $\begin{array}{c}3 \\
\text { Bln }\end{array}$ & $\begin{array}{c}6 \\
\text { BIn }\end{array}$ & $\begin{array}{c}9 \\
\text { BIn }\end{array}$ & $\begin{array}{c}12 \\
\text { Bln }\end{array}$ \\
\hline \multirow{3}{*}{$\begin{array}{l}\text { Meningkat- } \\
\text { kan kinerja } \\
\text { setiap PNS } \\
\text { di } \\
\text { lingkungan } \\
\text { BKKBN } \\
\text { Propinsi } \\
\text { Jawa Timur }\end{array}$} & Kehadiran PNS & Orang & 73 & 75 & 80 & 85 & 90 \\
\hline & $\begin{array}{l}\text { Kehadiran Apel } \\
\text { Pagi dan } \\
\text { Upacara }\end{array}$ & Orang & 80 & 85 & 90 & 95 & 100 \\
\hline & $\begin{array}{l}\text { Kegiatan Olah } \\
\text { Raga }\end{array}$ & Orang & 30 & 50 & 60 & 70 & 80 \\
\hline
\end{tabular}

Sumber: Kantor BKKBN Provinsi Jawa Timur.

Berdasarkan rekapitulasi dalam tabel 1 di atas menunjukkan ragam tingkat kehadiran pegawai di lingkungan BKKBN Provinsi Jawa Timur yang menyatakan hasil rata-rata tingkat kehadiran pegawai masih di bawah standart rata-rata yang ditentukan oleh Kantor BKKBN Provinsi Jawa Timur. Perubahan dan figur-figur tersebut pada dasarnya di lingkungan pegawai/karyawan dan pimpinan itu sendiri sangat berpengaruh terhadap perubahan kinerjanya, sehingga secara tidak langsung para pegawai akan dituntut untuk berkompetensi dan disiplin diri dalam meningkatkan kinerjanya. Rendahnya kinerja Pegawai Negeri Sipil pada BKKBN Provinsi Jawa Timur. disebabkan oleh berbagai faktor, baik karena faktor manusianya yang berkaitn dengan pendidikan, pengalaman, kondisi, fisik, disiplin, sikap dan perilaku maupun karena faktor organisasi/manajemen yang berkaitan dengan pola pikir, pengawasan, sistem kompensasi dan penghargaan serta faktor lingkungan kerja dan lingkungan keluarga.

Dalam rangka meningkatkan kinerja Pegawai Negeri Sipil, BKKBN Provinsi Jawa Timur telah melakukan upaya penerapan disiplin pegawai, pemberian kompensasi dan penghargaan sesuai dengan ketentuan dan kemampuan instansi serta upaya lainnya seperti pelaksanaan pendidikan dan pelatihan, penataan lingkungan kerja dan sebagainya. Penerapan disiplin pegawai dilaksanakan dengan mencatat kehadiran pegawai dengan menggunakan mesin absensi, melakukan pengawasan dan inspeksi mendadak pada jam kerja serta melarang pegawai keluar kantor pada jam kerja dan bagi yang melaksanakan tugas dinas ke luar kota harus membawa surat tugas. Penerapan disiplin pegawai tersebut di atas diikuti dengan sistem pemberian kompensasi berupa gaji, tunjangan dan fasilitas 
lainnya yang berhubungan dengan kesejahteraan pegawai. Dengan demikian maka penerapan disiplin, pemberian kompensasi dan pemberian penghargaan diharapkan sebagai alternatif upaya dalam mengatasi indikasi menurunnya kinerja Pegawai Negeri Sipil pada BKKBN Provinsi Jawa Timur dalam rangka mendukung kinerja instansi BKKBN Provinsi Jawa Timur. Oleh karena itu perlu diteliti tentang Kompensasi dan Penghargaan sebagai Intervening hubungan antara Penerapan Disiplin dan Kinerja Pegawai di BKKBN Provinsi Jawa Timur.

Berdasarkan uraian tersebut di atas, peneliti berkeinginan mengangkat permasalahan yang dianggap mendasar yaitu:

1. Apakah penerapan disiplin mempunyai pengaruh langsung secara signifikan terhadap kinerja Pegawai BKKBN Provinsi Jawa Timur

2. Apakah penerapan disiplin mempunyai pengaruh tidak langsung secara signifikan melalui pemberian kompensasi terhadap kinerja Pegawai BKKBN Provinsi Jawa Timur

3. Apakah penerapan disiplin mempunyai pengaruh tidak langsung secara signifikan melalui pemberian penghargaan terhadap kinerja pegawai BKKBN provinsi Jawa Timur

4. Apakah penerapan disiplin mempunyai pengaruh tidak langsung secara signifikan melalui pemberian kompensasi dan melalui pemberian penghargaan terhadap kinerja pegawai BKKBN Provinsi Jawa Timur

Adapun yang menjadi tujuan dari penelitian ini adalah sebagai berikut:

1. Untuk mengetahui pengaruh langsung penerapan disiplin terhadap kinerja pada Pegawai BKKBN Provinsi Jawa Timur.

2. Untuk mengetahui pengaruh tidak langsung antara penerapan disiplin terhadap kinerja melalui pemberian kompensasi pada Pegawai BKKBN Provinsi Jawa Timur.

3. Untuk mengetahui pengaruh tidak langsung antara penerapan disiplin terhadap kinerja melalui pemberian penghargaan pada Pegawai BKKBN Provinsi Jawa Timur.

4. Untuk mengetahui pengaruh tidak langsung antara penerapan disiplin terhadap kinerja melalui pemberian kompensasi dan melalui pemberian penghargaan pada Pegawai BKKBN Provinsi Jawa Timur.

\section{RERANGKA TEORETIS}

\section{Pengertian Disiplin}

Menurut Sulistiyani dan Rosidah (2003) disiplin (discipline) adalah prosedur yang mengoreksi atau menghukum bawahan karena melanggar peraturan atau prusedur. Selanjutnya dijelaskan bahwa disiplin merupakan bentuk pengendalian diri pegawai dan pelaksanaan yang teratur dan menunjukkan tingkat kesungguhan tim kerja didalam sebuah organisasi. Heidjrachman dan Husnan, (2002) mengungkapkan "Disiplin adalah 
Setiap perseorangan dan juga kelompok yang menjamin adanya kepatuhan terhadap perintah" dan berinisiatif untuk melakukan suatu tindakan yang diperlukan seandainya tidak ada perintah. Menurut Davis adalah tindakan manajemen untuk memberikan semangat kepada pelaksanaan standar organisasi, ini adalah pelatihan yang mengarah pada upaya membenarkan dan melibatkan pengetahuan-pengetahuan sikap dan perilaku pegawai sehingga ada kemauan pada diri pegawai untuk menuju pada kerjasama dan prestasi yang lebih baik". Disiplin itu sendiri diartikan sebagai kesediaan seseorang yang timbul dengan kesadaran sendiri untuk mengikuti peraturan-peraturan yang berlaku dalam organisasi. Dalam Peraturan Pemerintah Nomor 30 Tahun 1980 Tentang Peraturan Disiplin Pegawai Negeri Sipil telah diatur secara jelas bahwa kewajiban yang harus ditaati oleh setiap Pegawai Negeri Sipil merupakan bentuk disiplin yang ditanamkan kepada setiap Pegawai Negeri Sipil. Davis (1996) mengemukakan bahwa disiplin kerja dapat diartikan sebagai pelaksanaan manajemen untuk memperteguh pedoman-pedoman organisasi. Menurut Brannick (1995), Kedisiplinan lebih tepat kalau diartikan sebagai suatu sikap, tingkah laku dan perbuatan yang sesuai dengan peraturan dari perusahaan baik yang tertulis maupun tidak. Tujuan tindakan disipliner adalah positif, sifatnya mendidik dan memperbaiki perilaku dimasa yang akan datang dan bukan menghukum perilaku masa lalu. Tindakan disipliner yang paling terakhir adalah pemecatan, yaitu pemberhentian pegawai dari organisasi karena alasan tertentu. Ada yang berpendapat bahwa setiap pemecatan pegawai membuktikan kegagalan pimpinan, tetapi pandangan ini tidak realistik. Karena ada masalah tertentu yang tidak dapat ditangani betapapun orang berusaha keras menanggulanginya. Jadi dari pengertian-pengertian tersebut maka disiplin merupakan aturan-aturan tertentu dalam organisasi yang harus dilaksanakan atau ditaati oleh pegawai dalam organisasi yang bersangkutan.

\section{Pengertian Kompensasi}

Kompensasi meruPakan faktor penting yang mempengaruhi bagaimana dan mengapa orang-orang memilih untuk bekerja di sebuah organisasi daripada organisasi lainnya. Para pemberi kerja harus agak kompetitif dengan beberapa jenis kompensasi untuk menarik dan mempertahankan karyawan yang kompeten. Jadi pentingnya progam kompensasi bagi organisasi karena mencerminkan upaya organisasi untuk mempertahankan sumber daya manusia sebagai komponen utama. Disamping pertimbangan tersebut, kompensasi juga merupakan salah satu aspek yang berarti bagi pegawai karena bagi individu/pegawai besarnya kompensasi merupakan cerminan atau ukuran nilai terhadap kerja pegawai itu sendiri. Menurut Handoko (2001), kompensasi adalah segala sesuatu yang diterima para karyawan sebagai balas jasa untuk kerja mereka. Pengertian ini sama dengan Sedarmayanti (2001) bahwa kompensasi adalah segala sesuatu yang diterima oleh pegawai sebagai balas jasa untuk kerja mereka. Sedangkan menurut Simamora (2003) menyatakan bahwa Kompensasi merupakan apa yang diterima oleh para karyawan sebagai ganti kontribusi mereka kepada organisasi, seperti dijelaskan oleh Ranupandojo dan Husnan (2002) bahwa Kompensasi dapat didefinisikan sebagai pemberian penghargaan yang adil dan layak terhadap para karyawan sesuai dengan sumbangan 
mereka untuk mencapai tujuan organisasi. Menurut Sulistiyani dan Rosidah (2003 kompensasi adalah segala sesuatu yang diterima oleh pegawai sebagai balas jasa (kontra prestasi) atas kerja mereka. Pada dasarnya kompensasi merupakan konstribusi yang diterima oleh pegawai atas pekerjaan yang telah dikerjakannya. Selanjutnya Collins et al (2004) memberi pengertian bahwa kompensasi adalah apa yang diterima pegawai sebagai pertukaran pekerjaannya. Sedangkan Irianto (2001) menyebutkan bahwa kompensasi merupakan bentuk penghargaan atau 'reward'. Jadi dengan demikian kopensasi merupakan balas jasa atau imbalan yang diberikan oleh organisasi (tempat bekerja pegawai) sebagai konstribusi atas pekerjaan yang telah dilaksanakan oleh para pegawai. Besar kecilnya kompensasi yang diberikan oleh organisasi tergantung kepada besar kecil sumbangan tenaga dan pikiran yang diberikan kepada organisasi. Dari penjelasan diatas, dapat disimpulkan bahwa kompensasi adalah segala sesuatu yang diterima oleh karyawan sebagai balas jasa untuk aktivitas kerja mereka.

\section{Pengertian Penghargaan}

Menurut Mc. Kenna dan Beech (2002) menyebutkan bahwa: "Dalam konteks MSDM, manajemen rewards tidak dibatasi pada pemberian rewards dan insentif, misalnya upah atau gaji, bonus, komisi dan pembagian laba, yang berhubungan dengan motivasi ekstrinstik. Hal diatas juga berkaitan dengan rewards non finansial yang memuaskan kebutuhan psykologi karyawan akan varietas dan tantangan pekerjaan, prestasi, pengakuan, tanggung jawab, kesempatan untuk memperoleh pengembangan ketrampilan dan karier, dan pelaksanaan pengaruh yang lebih besar dalam proses pengambilan keputusan". Sejalan dengan hal tersebut, dijelaskan pula oleh Irianto (2001) bahwa secara tradisional, sistim penghargaan berbeda dengan sistem kompensasi. Sistem ini hanya berkaitan dengan aspek-aspek ekonomi atau keuangan (monetary) sebagai bagian dari sistem penghargaan. Ranupandojo dan Husnan (2002) menjelaskan bahwa kebanyakan manusia senang menerima pengakuan terhadap pekerjaan yang diselesaikan dengan baik jadi, bagaimana penghargaan terhadap pekerjaan yang terselesaikan dengan baik akan menyenangkan karyawan tersebut.

Irianto (2001) memberikan pengertian bahwa segala sesuatu yang diberikan organisasi untuk memuaskan satu atau beberapa kebutuhan individu dapat disebut sebagai penghargaan atau reward. Dess et al., (1997) juga memberikan penjelasan sebagai berikut: "Manusia berkarya tidak lagi untuk sekedar mencari nafkah meskipun hal itu tetap penting melainkan sebagai wahana untuk mengangkat harkat dan martabat. Berarti untuk memuaskan kebutuhan "harga Diri", antara lain melalui perolehan pengakuan dan penghargaan dari orang lain, seperti atasan, rekan setingkat dan bahkan para bawahan". Berdasarkan penjelasan-penjelasan tersebut, maka penghargaan yang dimaksud adalah penghargaan (rewards) intrinsik yaitu penghargaan yang bersifat non material atau non finansial. Sedangkan kompensasi merupakan salah satu bentuk penghargaan yaitu berupa imbalan yang berkaitan dengan materi atau ekonomis yang berhubungan dengan pemenuhan kebutuhan dasar. 


\section{Pengertian Kinerja}

Bilamana suatu organisasi atau perusahaan membuat rencana pemindahan dan promosi pegawai, maka harus diadakan penilaian dari kinerja pegawai (Boles et al., 1997). Penilaian kinerja pegawai merupakan salah satu alternatif dasar dalam pemindahan atau promosi pegawai, alternatifnya adalah senioritas, di antara kedua alternatif tersebut dapat ditinjau dari nilai obyektivitasnya dan penilaian pegawai lebih memenuhi persyaratan, namun dalam praktek masing-masing alternatif ada penganutnya. Menurut Floyd \& Lane (2000), menyatakan bahwa kinerja suatu hasil kerja yang dapat dicapai oleh seseorang atau kelompok orang dalam suatu organisasi, sesuai dengan wewenang dan tanggungjawab masing-masing dalam rangka mencapai tujuan organisasi bersangkutan secara legal, tidak melanggar hukum, dan sesuai dengan moral dan etika. Pendapat Johnson (1990), menjelaskan bahwa penilaian kinerja adalah sebuah mekanisme untuk memastikan orang-orang pada tiap tingkatan mengerjakan tugas-tugas menurut cara yang diinginkan oleh pimpinan mereka. Selanjutnya tampilan atas pelaksanaan pekerjaan yang ditugaskan dengan menunjuk pada keberhasilan atau prestasi kerja tersebut kinerja (performance). Hal ini sesuai dengan pengertian kinerja yang menyebutkan, bahwa performance diterjemahkan menjadi kinerja, juga berarti prestasi kerja, pelaksanaan kerja, pencapaian kerja atau hasil kerja/unjuk kerja/penampilan kerja (LAN dalam Sedarmayanti, 2001). Boles et al (1997), menjelaskan penilaian pegawai dirumuskan sebagai suatu penilaian secara sistematis kepada pegawai oleh beberapa orang ahli untuk suatu atau beberapa tujuan tertentu. Menurut O'Driscoll \& Beehr (1994) menjelaskan bahwa kinerja merupakan hasil kerja yang dicapai oleh seseorang atau sekelompok dalam suatu organisasi dalam kurun waktu tertentu, sesuai dengan wewenang dan tanggungjawab masing-masing. Menurut Mangkunegaran (2001), menyatakan kinerja adalah hasil kerja secara kualitas dan kuantitas yang dicapai oleh seorang pegawai dalam melaksanakan tugasnya sesuai dengan tanggung jawab yang diberikan kepadanya. Selanjutnya untuk memperjelas mengenai kinerja instansi pemerintah di negara indonesia ini, maka pemerintah mengeluarkan Inpres RI no 7 Tahun 1999 tentang Akuntabilitas Kinerja Instansi Pemerintah yang dalam pelaksanaannya ditindaklanjuti dengan Keputusan Kepala lembaga Administrasi Negara nomor: 589/IX/6A71999 tentang Pedoman Penyusunan Pelaporan Akuntabilitas Kinerja Instansi Pemerintah. Dalam keputusan tersebut dijelaskan bahwa kinerja adalah "Gambaran mengenai tingkat pencapaian pelaksanaan suatu kegiatan/program /kebijaksanaan dalam mewujudkan sasaran, tujuan, misi dan visi organisasi. Kinerja dimaksud dipertanggungjawabkan kepada pihak yang memiliki hak atau berkewenangan untuk meminta keterangan atau pertanggungjawaban”.

\section{Penelitian Terdahulu}

Lee \& Kamarul (2009) melakukan penelitian mengenai kinerja karyawan, kepuasan kerja dikaitkan dengan kepemimpinan dan komitmen organisasi di Malaysia. Data dikumpulkan melalui 238 mahasiswa paruh waktu program MBA University of Malaya, Kuala Lumpur. Kuesioner terdiri dari variabel budaya organisasi dan perilaku 
kepemimpinan serta bagaimana hal tersebut dapat mempengaruhi kinerja karyawan, komitmen organisasi dan kepuasan kerja. Ada 4 hipotesis yang dikembangkan dan salah satunya adalah hubungan antara komitmen organisasi dengan kinerja karyawan dan kepuasan kerja. Hasil pengujian melalui "hierarchical multiple regression" menunjukkan bahwa komitmen organisasi tidak mempunyai hubungan yang signifikan terhadap kinerja karyawan dan kepuasan kerja. Komitmen organisasi hanya mampu menerangkan sebesar $17,9 \%$ dari variasi kepuasan kerja dan komitmen organisasi hanya mampu menjelaskan $1,4 \%$ dari variasi kinerja karyawan.

Steve at al., (2005) melakukan penelitian tentang sensitivitas budaya perusahaan, kualitas pelayanan pelanggan, perilaku konsumen di Amerika Serikat. Ada 44 hotel berbintang 4 dan bintang 5 di Florida yang akan digunakan dalam studi ini, namun 27 hotel saja yang bersedia untuk berpartisipasi. Total responden adalah 383 pengunjung hotel dengan tingkat pengembalian adalah $60,1 \%$ atau 230 orang. Teknik analisis data yang digunakan adalah korelasi Pearson dan Analysis of Variance (ANOVA). Dalam penelitian tersebut penghargaan dibagi menjadi 2 (dua) yaitu penghargaan utama (primary reward) yang berupa gaji, tips, bonus dan penghargaan kedua (secondary reward) yang berupa penghargaan non material. Penghargaan merupakan salah satu komponen dari sensitivitas budaya perusahaan. Hasilnya adalah sensitivitas budaya perusahaan mempunyai hubungan yang signifikan terhadap kualitas pelayanan pelanggan dan perilaku konsumen. Dalam penelitian ini penghargaan yang merupakan salah satu komponen dari sensitivitas budaya perusahaan berperan sebagai variabel bebas.

Darden et al., (1993) melakukan penelitian model kepuasan kerja dengan status karyawan sebagai variabel moderating di Amerika Serikat. Status karyawan dibagi menjadi 2 (dua) yaitu karyawan penuh waktu dan karyawan paruh waktu, sedang variabel yang digunakan adalah gaya partisipasi, komitmen organisasi, tingkat keterlibatan, kepuasan kerja dan kinerja. Populasi dari penelitian ini adalah karyawan pada toko tradisional, teknik sampling yang digunakan adalah proporsional random sampling. Ada 700 karyawan dari 63 toko tradisional sebagai populasi, kuesioner dikirim melalui email. Tingkat pengembalian adalah $39 \%$, dan yang dapat digunakan adalah $37 \%$. Total sampel adalah 263 karayawan yang terdiri 144 karyawan penuh waktu dan 117 karyawan paruh waktu. Teknik statistik yang digunakan adalah uji reliabilitas, chi-square dan lisrel multi-sample analysis. Ada 3 buah hipotesis yang dikembangkan yaitu hipotesis pertama, status karyawan memoderasi hubungan antara gaya partisipasi dengan kepuasan kerja dan kinerja karyawan, hipotesis kedua status karyawan memoderasi hubungan antara komitmen organisasi dengan kepuasan kerja dan hipotesis ketiga adalah status karyawan memoderasi hubungan antara keterlibatan kerja dengan kepuasan kerja. Hasil penelitian yang terkait dengan kinerja karyawan adalah gaya partisipasi mempunyai pengaruh signifikan terhadap kinerja karyawan paruh waktu dan tidak berpengaruh signifikan terhadap karyawan penuh waktu. 
Darwish (1998) meneliti tentang kepuasan, keamanan kerja, komitmen organisasi dan kinerja karyawan pada lingkungan multikultural namun bukan negara barat di Arab Saudi. Populasi penelitian ini adalah para pekerja expatriate dari seluruh dunia yang merupakan $70 \%$ pekerja di Arab Saudi, sedangkan dari Arab Saudi sendiri hanya 30 \%. Dari 650 kuesioner yang disebarkan, terkumpul 447 data atau $69 \%$ tingkat pengembaliannya. Untuk kepuasan pada keamanan kerja menggunakan kuesioner dari Minnesota Satisfaction Questionnaire (MSQ) yang dikembangkan oleh Lysonski, S., \& Andrews, G. (1990). Komitmen organisasi diukur menggunakan instrument yang dikembangkan oleh Beehr et al (2000). Kinerja karyawan diukur dengan pendekatan penilaian diri. Ada 5 hipotesis yang dikembangkan dalam penelitian ini, pada hipotesis kedua menyatakan bahwa terdapat hubungan positif signifikan antara kepuasan dalam keamanan kerja dengan kinerja karyawan. Teknik statistik yang digunakan adalah statistik deskriptif menggunakan analisis frekuensi dan statistik induktif menggunakan korelasi Pearson, Statistik-F dan analisis regresi untuk menguji validitas dari hipotesis. Hasilnya yang berkaitan dengan kinerja karyawan yaitu hipotesis kedua menunjukkan terdapat hubungan positif walaupun tidak sangat kuat antara kepuasan dalam keamanan kerja dengan kinerja karyawan.

Darwish (2000) meneliti tentang komitmen organisasi, perilaku kepemimpinan, kepuasan kerja dan kinerja karyawan. Populasi adalah 50 buah organisasi pada 4 distrik utama di Arab Saudi. Kemudian diambil 30 organisasi secara random atau $60 \%$ dari populasi, kemudian 600 kuesioner disebarkan pada 30 organisasi tersebut dan terkumpul kembali sebanyak 500 kuesioner sedangkan yang bias digunakan adalah 430 kuesioner. Tingkat pengembalian kuesioner pada penelitian ini adalah $72 \%$. Responden adalah pekerja individu pada berbagai organisasi di Arab Saudi, $88 \%$ bekerja pada perusahaan jasa. Ada 3 buah hipotesis yang dikembangkan yaitu hipotesis pertama menyatakan bahwa kebangsaan memoderasi hubungan antara perilaku kepemimpinan dengan komitmen organisasi, kepuasan kerja dan kinerja karyawan. Hipotesis kedua menyatakan bahwa komitmen organisasi memediasi hubungan antara perilaku kepemimpinan dengan kepuasan karyawan dan kinerja karyawan dan hipotesis ketiga menyatakan bahwa kebangsaan memoderasi hubungan antara komitmen organisasi dengan kepuasan kerja dan kinerja karyawan. Teknik statistik yang digunakan adalah regresi berganda dengan variabel moderating. Hasilnya pengujian hipotesis pertama dan hipotesis ketiga menunjukkan bahwa variabel kebangsaan mampu memoderasi hubungan antara perilaku kepemimpinan dan komitmen organisasi, kepuasan kerja dan kinerja karyawan, dan juga komitmen organisasi dan keduanya kepuasan kerja dan kinerja karyawan. Hasil pengujian hipotesis kedua menunjukkan bahwa variabel kebangsaan mampu memediasi hunungan antara gaya kepemimpinan dengan keduanya kepuasan kerja dan kinerja karyawan.

\section{Kerangka Konseptual}

Kerangka konseptual ini dibentuk atas dasar kajian teori yang telah diuraikan sebelumnya. Dari kajian teori tersebut maka dalam penelitian ini terdapat dua variabel yaitu variabel 
bebas (dependen variable) dan variabel terikat (indeenden variable). Dengan demikian kerangka konseptual penelitian ini ditunjukkan pada gambar 1 .

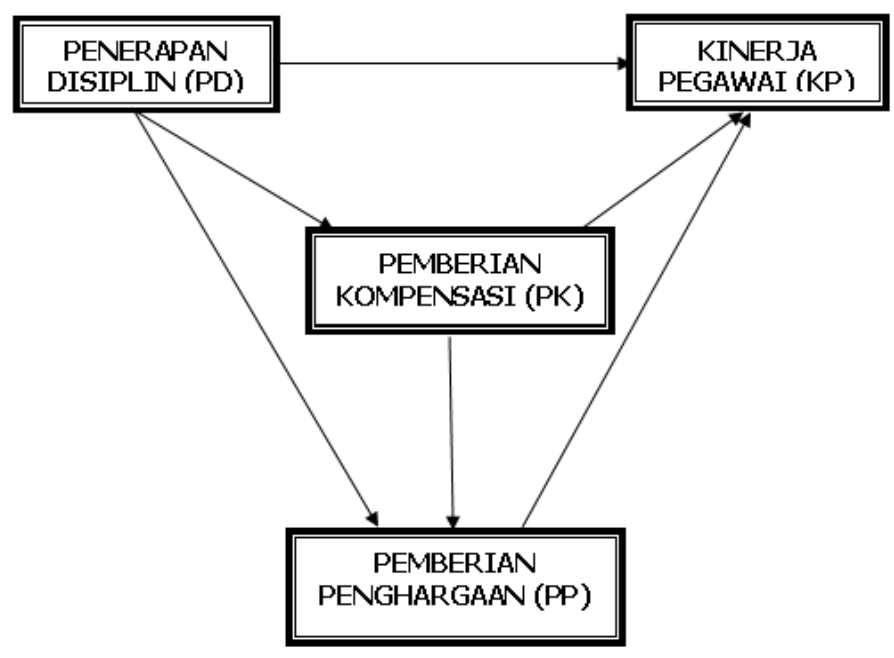

Gambar 1

Kerangka Konseptual

Kerangka konseptual di atas menjelaskan bahwa analisa yang dilakukan adalah untuk mengetahui pengaruh langsung variabel penerapan disiplin terhadap kinerja pegawai. Untuk mengetahui pengaruh tidak langsung antara variabel Penerapan Disiplin terhadap Kinerja Pegawai dan Pemberian Kompensasi sebagai variabel intervening. Untuk mengetahui pengaruh tidak langsung antara variabel Penerapan Disiplin terhadap Kinerja Pegawai dan Pemberian Penghargaan sebagai variabel intervening pada Kantor BKKBN Provinsi Jawa Timur.

\section{Hipotesis Penelitian}

Berdasarkan kerangka konseptual di atas maka hipotesis dalam penelitian ini adalah:

1. Penerapan disiplin berpengaruh langsung secara signifikan terhadap kinerja Pegawai BKKBN Provinsi Jawa Timur

2. Penerapan disiplin berpengaruh tidak langsung melalui pemberian kompensasi secara signifikan terhadap kinerja Pegawai BKKBN Provinsi Jawa Timur

3. Penerapan disiplin berpengaruh tidak langsung melalui pemberian penghargaan secara signifikan terhadap kinerja Pegawai BKKBN Provinsi Jawa Timur

4. Penerapan disiplin berpengaruh tidak langsung melalui pemberian kompensasi dan melalui pemberian penghargaan terhadap kinerja Pegawai BKKBN Provinsi Jawa Timur 


\section{METODOLOGI PENELITIAN}

\section{Jenis Penelitian, Gambaran Populasi dan Penentuan Jumlah Sampel}

Jenis penelitian ini menggunakan metode penelitian survey dengan pendekatan penelitian kuantitatif. Pendekatan ini menitik beratkan pada pengujian hipotesis, data yang digunakan harus terukur, dan akan menghasilkan kesimpulan yang dapat digeneralisir. Pendekatan ini dimulai dengan hipotesa dan teori-teori, model analisis, mengidentifikasi variabel, membuat definisi operasional, mengumpulkan data (baik primer maupun sekunder) berdasarkan populasi dan sampel serta melakukan analisis. Menurut Sugiono (2007) adalah wilayah generalisasi yang terdiri atas obyek-obyek yang mempunyai kuantitas dan karakteristik tertentu yang ditetapkan oleh peneliti untuk dipelajari dan kemudian ditarik kesimpulannya.

Berdasarkan definisi tersebut, maka populasi dalam penelitian ini adalah Pegawai BKKBN Provinsi Jawa Timur sebanyak 141 orang pegawai. Sampel adalah meneliti sebagian dari elemen-elemen populasi atau dengan kata lain sampel adalah bagian dari jumlah dan karakteristik yang dimiliki oleh populasi tersebut (Sugiono : 2007). Pada penelitian ini yang merupakan sampel adalah Pegawai BKKBN Provinsi Jawa Timur. Dan menggunakan teknik cluster sampling yang nantinya diambil secara random sampling yang berdasarkan dari jumlah populasi. Cara pengambilan atau memperoleh sampel dilakukan dengan penghitungan proporsional masing-masing bidang diambil 58\% dari populasi (sebanyak 141 pegawai), maka jumlah sampelnya sebanyak 82 orang responden. Cara perhitungan, seperti tampak pada tabel 2.

Tabel 2

Daftar Pengambilan Jumlah Sampel

\begin{tabular}{|c|c|c|c|c|}
\hline No. & Bidang & $\begin{array}{l}\text { Pegawai } \\
\text { Sebagai } \\
\text { Populasi }\end{array}$ & $\begin{array}{l}\text { Jumlah Sampel } \\
(82 / 141 \times 100 \%)= \\
58 \% x P o p u l a s i \\
\end{array}$ & $\begin{array}{c}\text { Jumlah } \\
\text { Sampel } \\
\text { (Dibulatkan) } \\
\end{array}$ \\
\hline 1. & Sekretaris & 69 orang & 40,02 & 40 \\
\hline 2. & KB-KR & 22 orang & 12,76 & 13 \\
\hline 3. & KS-PK & 21 orang & 12,18 & 12 \\
\hline 4. & IKAP & 16 orang & 9,28 & 9 \\
\hline \multirow[t]{2}{*}{5.} & Supervisi & 13 orang & 7,54 & 8 \\
\hline & Jumlah & 141 orang & 82 & 82 \\
\hline
\end{tabular}

Sumber : Subag. Hukum dan Kepegawaian BKKBN Prov. Jatim

\section{Definisi Operasional}

Untuk menghindari kekeliruan dalam memahami variabel-variabel ini, maka perlu dijelaskan pengertian variabel yang dalam penelitian digunakan dalam model analisis penelitian ini yaitu: 
a. Penerapan Disiplin (PD) yaitu penerapan disiplin Pegawai Negeri Sipil yang berupa kewajiban yang harus dilakukan dan larangan yang harus ditaati oleh seluruh pegawai pada Kantor BKKBN Provinsi Jawa Timur

Adapun Indikator Variabel yang digunakan adalah:

1) Kewajiban yang harus dilakukan

Disiplin terhadap waktu

Disiplin terhadap Peraturan Pemerintah No 30 Tahun 1980 tentang Peraturan Disiplin PNS

2) Larangan yang harus di taati

Pemahaman akibat pelanggaran disiplin

Pemahaman tentang kode etik Kepegawaian

Kemampuan melaksanakan kode etik kepegawaian

b. Pemberian Kompensasi (PK) yaitu imbalan yang diberikan kepada pegawai atas pekerjaan yang telah dilaksanakan oleh Pegawai. Adapun Indikator yang digunakan adalah:

1. Gaji pokok - adalah jumlah yang disetujui untuk sesuatu pekerjan

2. Insentive - pemberian imbalan berupa uang sebagai balas jasa atas pekerjaan yang telah diberikan untuk mencapai tujuan organisasi.

3. Perjalanan Dinas - Perjalanan keluar dari tempat kedudukan yang jaraknya sekurang-kurangnya 5 (lima) $\mathrm{Km}$ dari batas kota, yang dilakukan untuk kepentingan Negara atas perintah yang berwenang.

4. Pemberian Pelayanan Pemeriksaan Kesehatan - Adanya Dokter jaga yang setiap hari melayani Pemeriksaan untuk PNS BKKBN Provinsi Jawa Timur

c. Pemberian Penghargaan (PP) yaitu pemberian penghargaan oleh pimpinan/atasan terhadap prestasi kerja Pegawa Negeri Sipil

Adapun Indikator yang digunakan adalah :

1) Kenaikan pangkat - Penghargaan diberikan atas Prestasi Kerja dan Pengabdian

2) Promosi jabatan - Penghargaan yang diberikan atas penilaian kinerja pegawai secara obyektivitas

3) Penghargaan - Pengakuan terhadap pekerjaan yang telah diselesaikan dengan baik dan loyalitas terhadap organisasi. Pengakuan melalui pujian secara lisan, pemberian hadiah serta bentuk penghargaan lainnya.

d. Kinerja Pegawai (KP) yaitu pelaksana pekerjaan Pegawai Negeri Sipil untuk mendukung penyelesaian tugas-tugas pada instansi BKKBN Provinsi Jawa Timur yang diukur dari penyelesaian kegiatan dalam Kontrak Kerja Kemitraan dan Anggaran Pendapatan dan Belanja Negara yang ada di BKKBN Provinsi Jawa Timur. Adapun Indikator yang digunakan adalah :

1) Kualitas - Mempunyai kemampuan, menguasai bidang tugasnya dan mampu menyelesaikan masalah yang dihadapi

2) Kuantitas - Mempunyai pengalaman yang luas dibidang tugasnya dan mampu menyelesaikan tugas sesuai waktu yang ditetapkan serta sesuai dengan harapan pemimpin. 
3) Ketepatan Waktu - sesuai tidaknya dengan waktu yang direncanakan.

\section{Pengukuran Variabel}

Pengukuran variabel dilakukan dengan memberikan kuesioner berdasarkan definisi operasional diatas. Pengukuran jawaban dalam bentuk skala interval (Interval scale) yang merupakan skala pengukuran yang menyatakan katagori peringkat dan jarak construct yang diukur (Babin \& Boles, 1998), sedangkan metode pengukuran sikapnya menggunakan skala likert (Likert Scale) yaitu metode yang mengukur sikap dengan menyatakan selalu dan kurang sekali terhadap subyek, obyek atau kejadian tertentu, angka penilaian empat (4) yang menyatakan selalu dan angka penilaian satu (1) kurang sekali

\section{Teknik Analisa Data}

Teknik analisis data yang digunakan adalah Analisis Jalur (Path Analysis) yang bertujuan untuk mengetahui pengaruh langsung Penerapan Disiplin terhadap kinerja karyawan dan pengaruh tidak langsungnya melalui intervening Pemberian Kompensasi dan Pemberian Penghargaan seperti yang ditunjukkan pada gambar 2 .

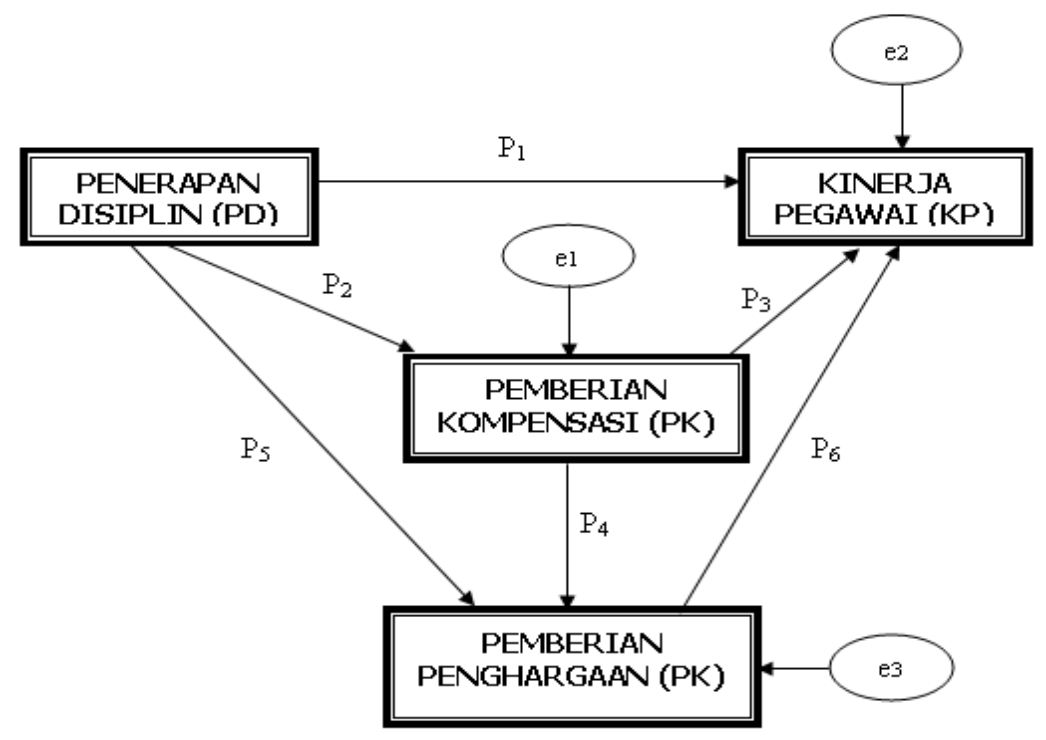

Gambar 2

Model Analisis Jalur (Path Analysis)

Analisis jalur merupakan perluasan dari analisis regresi linier berganda. Analisis jalur menggunakan analisa regresi untuk menaksir hubungan kausalitas antar variabel yang telah ditetapkan sebelumnya berdasarkan teori. Menurut Wibowo (2003) langkah-langkah untuk melakukan path analysis adalah sebagai berikut: 
1. Menentukan hubungan antara variabel dalam model adalah linier sesuai dengan teori yang ada.

2. Membuat diagram jalur sebagai model kausal

3. Menghitung koefisien jalur dalam model kausal tersebut

\section{Pengaruh Langsung Penerapan Disiplin terhadap Kinerja Pegawai}

Hubungan langsung terjadi jika satu variabel mempengaruhi variabel lainnya tanpa ada variabel ketiga atau keempat yang memediasi (intervening) hubungan kedua variabel tadi. Hubungan tidak langsung adalah jika ada variabel ketiga atau keempat yang memediasi hubungan kedua variabel tersebut. Kemudian pada setiap variabel dependen (endogen variabel) akan ada anak panah yang menuju ke variabel ini dan berfungsi untuk menjelaskan jumlah variance yang tidak dapat dijelaskan oleh variabel lain.Koefisien jalur adalah standardized koefisien $(\beta)$ Koefisien jalur dihitung dengan membuat persamaan regresi yang menunjukkan hubungan yang dihipotesiskan, Dalam hal ini adalah:

Kinerja Pegawai $=\beta_{1}$ penerapan disiplin $+\beta_{2}$ pemberian kompensasi $+\beta_{3}$ pemberian penghargaan $+\varepsilon$

Standardized koefisien untuk penerapan disiplin, pemberian kompensasi dan penghargaan pada persamaan tersebut akan memberikan nilai $p_{1}$ sebesar $\beta_{1}$, p 3 sebesar $\beta_{2}$ dan $\mathrm{p}_{6}$ sebesar $\beta_{3}$. Besarnya pengaruh langsung penerapan disiplin terhadap kinerja pegawai BKKBN Provinsi Jawa Timur adalah $p_{1}$ atau sebesar $\beta_{1}$.

\section{Pengaruh tidak langsung penerapan disiplin terhadap kinerja melalui pemberian} kompensasi dan melalui pemberian penghargaan sebagai variabel intervening.

Dari diagram jalur pada gambar 2 terdapat 3 (tiga) persamaan struktural sebagai berikut:

1. Pemberian Kompensasi $(\mathrm{PK})=\beta_{1}$ Penerapan Disiplin $+\varepsilon_{1}$

2. Kinerja Pegawai $(\mathrm{KP})=\beta_{1}$ Penerapan Disiplin $+\beta_{1}$ Pemberian Kompensasi $+\beta_{1}$ Pemberian Penghargaan $+\varepsilon_{2}$

3. Pemberian Penghargaan $(\mathrm{PP})=\beta_{1}$ Penerapan Disiplin $+\beta_{1}$ Pemberian Kompensasi + $\varepsilon_{3}$

Ada 3 buah pengaruh tidak langsung dari Penerapan Disiplin terhadap Kinerja Karyawan yaitu: Pertama pengaruh tidak langsung melalui pemberian kompensasi yang nilainya adalah sebesar $\mathrm{p}_{2}$ dikalikan $\mathrm{p}_{3}\left(\mathrm{p}_{2} * \mathrm{p}_{3}\right)$. Kedua pengaruh tidak langsung melalui pemberian kompensasi diteruskan melalui pemberian penghargaan yang nilainya sebesar $\mathrm{p}_{2}$ dikalikan $\mathrm{p}_{4}$ dikalikan $\mathrm{p}_{6}\left(\mathrm{p}_{2}{ }^{*} \mathrm{p}_{4} * \mathrm{p}_{6}\right)$ dan Ketiga adalah pengaruh tidak langsung melalui pemberian penghargaan yang nilainya sebesar $\mathrm{p}_{5}$ dikalikan $\mathrm{p}_{6}\left(\mathrm{p}_{5} * \mathrm{p}_{6}\right)$. Sehingga total pengaruh tidak langsung merupakan penjumlahan dari pengaruh tidak langsung pertama $\left(\mathrm{p}_{2} * \mathrm{p}_{3}\right)$ ditambah dengan pengaruh tidak langsung kedua $\left(\mathrm{p}_{2} * \mathrm{p}_{4} * \mathrm{p}_{6}\right)$ ditambah lagi dengan pengaruh tidak langsung ketiga $\left(\mathrm{p}_{5} * \mathrm{p}_{6}\right)$. 


\section{ANALISIS DAN PEMBAHASAN}

Hasil perhitungan parameter dari setiap hubungan yang ada pada model dan perhitungan epsilon dari 3 persamaan struktural ditunjukkan pada gambar 3 .

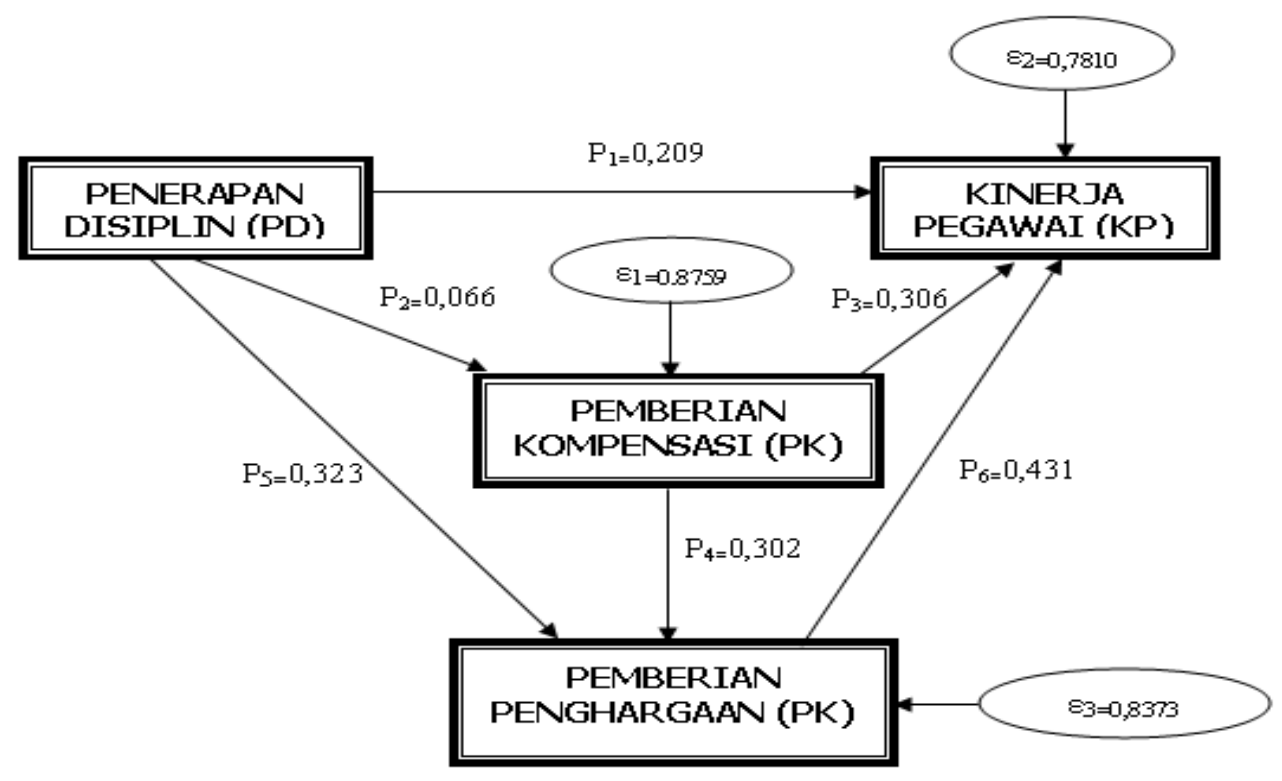

Gambar 3

Hasil perhitungan parameter dan epsilon

Penjelasan perhitungan dari masing-masing parameter, signifikansi hubungan dan perhitungan nilai epsilonnya adalah sebagai berikut:

Hasil perhitungan koefisien persamaan struktural pertama ditunjukkan pada tabel 3,

Tabel 3

Koefisien persamaan struktural pertama

\begin{tabular}{|c|c|c|c|c|c|c|c|c|}
\hline \multirow{2}{*}{\multicolumn{2}{|c|}{ Model }} & \multicolumn{2}{|c|}{$\begin{array}{c}\text { Unstandardized } \\
\text { Coefficients }\end{array}$} & \multirow{2}{*}{$\begin{array}{c}\text { Standardi } \\
\text { zed } \\
\text { Coefficien } \\
\text { ts }\end{array}$} & \multirow[b]{2}{*}{$\mathrm{t}$} & \multirow[b]{2}{*}{ Sig. } & \multicolumn{2}{|c|}{ Collinearity Statistics } \\
\hline & & B & Std. Error & & & & Tolerance & VIF \\
\hline & (Constant) & 1,355 & $\overline{3,668}$ & &, 369 & 071 & & \\
\hline & Penerapan Disiplin & ,652 & 1,105 & ,066 & 2,590 & ,036 & 1,000 & 1,000 \\
\hline
\end{tabular}

a. Dependent Variable: Pemberian Kompensasi 
Dari tabel 3, persamaan struktural dapat dibentuk dengan melihat koefisien Standardized Coefficient (Beta), sehingga persamaan struktural pertama yang dihasilkan adalah:

Pemberian Kompensasi $=0,066$ Penerapan Disiplin $+\varepsilon_{1}$ (persamaan 1)

Dari persamaan 1, parameter pengaruh penerapan disiplin terhadap pemberian kompensasi adalah $\mathrm{p}_{2}$ sebesar 0,066 dan pengaruhnya adalah signifikan karena nilai signifikansinya lebih kecil dari 0,05 ( $\mathrm{sig}=0,036)$, sedangkan nilai $\mathrm{R}^{2}$ dari persamaan struktural pertama melalui perhitungan SPSS adalah 0,2328. Nilai $\varepsilon_{1}$ adalah akar dari 1 dikurangi $\mathrm{R}^{2}$ (Ghozali, 2009) sehingga nilainya sebesar :

$\varepsilon_{1}=\sqrt{\left(1-R^{2}\right)}=\sqrt{(1-0,2328)}=0,8759$

Hasil perhitungan koefisien persamaan struktural kedua ditunjukkan pada tabel 4 ,

Tabel 4

\section{Koefisien persamaan struktural kedua}

\begin{tabular}{|c|c|c|c|c|c|c|c|c|}
\hline \multirow[b]{2}{*}{ Model } & & \multicolumn{2}{|c|}{$\begin{array}{c}\text { Unstandardized } \\
\text { Coefficients }\end{array}$} & \multirow[t]{2}{*}{\begin{tabular}{|c|}
$\begin{array}{c}\text { Standardi } \\
\text { zed } \\
\text { Coefficien } \\
\text { ts }\end{array}$ \\
Beta \\
\end{tabular}} & \multirow[b]{2}{*}{$t$} & \multirow[b]{2}{*}{ Sig. } & \multicolumn{2}{|c|}{ Collinearity Statistics } \\
\hline & & B & Std. Error & & & & Tolerance & VIF \\
\hline \multirow[t]{4}{*}{1} & (Constant) & 2,561 &, 532 & & 4,812 & ,000 & & \\
\hline & Penerapan Disiplin & ,885E-02 & 114 & ,209 & 2,778 & 020 & ,995 & 1,005 \\
\hline & Pemberian Kompensas & $;, 559 E-11$ & ,115 & ,306 & 2,483 & ,026 & ,995 & 1,049 \\
\hline & Pemberian Penghargaa & ,146 & ,126 & ,431 & 2,816 &, 012 & ,998 & 1,002 \\
\hline
\end{tabular}

a. Dependent Variable: Kinerja

Dari tabel 4, persamaan struktural dapat dibentuk dengan melihat koefisien Standardized Coefficient (Beta), sehingga persamaan struktural kedua yang dihasilkan adalah:

$$
\begin{aligned}
& \text { Kinerja }=0,209 \text { Penerapan Disiplin }+0,306 \text { Pemberian Kompensasi }+ \\
& 0,431 \text { Pemberian Penghargaan }+\varepsilon_{2} \ldots \ldots \ldots \ldots \ldots \ldots \ldots \ldots \ldots \ldots \ldots \ldots \ldots \ldots \ldots \ldots \ldots \ldots \ldots \ldots \ldots \ldots \ldots \ldots \ldots \\
& \text { (persamaan 2) }
\end{aligned}
$$

Dari persamaan 2, parameter pengaruh penerapan disiplin terhadap kinerja adalah $\mathrm{p}_{1}$ sebesar 0,209 dan pengaruhnya adalah signifikan karena nilai signifikansinya lebih kecil dari 0,05 (sig $=0,020)$, parameter pengaruh pemberian kompensasi terhadap kinerja adalah $\mathrm{p}_{3}$ sebesar 0,306 dan pengaruhnya adalah signifikan karena nilai signifikansinya lebih kecil dari 0,05 ( $\mathrm{sig}=0,026)$, parameter pengaruh pemberian penghargaan terhadap kinerja adalah $\mathrm{p}_{6}$ sebesar 0,431 dan pengaruhnya adalah signifikan karena nilai signifikansinya lebih kecil dari 0,05 ( $\mathrm{sig}=0,012)$, sedangkan nilai $\mathrm{R}^{2}$ dari persamaan struktural kedua melalui perhitungan SPSS adalah 0,390. Nilai $\varepsilon_{2}$ adalah akar dari 1 dikurangi $\mathrm{R}^{2}$ (Ghozali, 2009) sehingga nilainya sebesar: 


$$
\varepsilon_{2}=\sqrt{\left(1-R^{2}\right)}=\sqrt{(1-0,390)}=0,7810
$$

Hasil perhitungan koefisien persamaan struktural ketiga ditunjukkan pada tabel 5,

Tabel 5

Koefisien persamaan struktural ketiga

\begin{tabular}{|c|c|c|c|c|c|c|c|c|}
\hline \multirow[b]{2}{*}{ Model } & & \multicolumn{2}{|c|}{$\begin{array}{c}\text { Unstandardized } \\
\text { Coefficients }\end{array}$} & \multirow[t]{2}{*}{\begin{tabular}{|c|}
$\begin{array}{c}\text { Standardi } \\
\text { zed } \\
\text { Coefficien } \\
\text { ts }\end{array}$ \\
Beta \\
\end{tabular}} & \multirow[b]{2}{*}{$\mathrm{t}$} & \multirow[b]{2}{*}{ Sig. } & \multicolumn{2}{|c|}{ Collinearity Statistics } \\
\hline & & $\mathrm{B}$ & Std. Error & & & & Tolerance & VIF \\
\hline & (Constant) & 2,963 & ,337 & & 8,803 &, 000 & & \\
\hline & Penerapan Disiplin & ,305 & ,102 & ,323 & 2,030 & ,039 & ,985 & 1,043 \\
\hline & Pemberian Kompensa & , 459 & ,250 & ,302 & 2,294 & ,042 & ,996 & 1,004 \\
\hline
\end{tabular}

a. Dependent Variable: Pemberian Penghargaan

Dari tabel 5, persamaan struktural dapat dibentuk dengan melihat koefisien Standardized Coefficient (Beta), sehingga persamaan struktural ketiga yang dihasilkan adalah:

$$
\begin{array}{r}
\text { Pemberian Penghargaan }=0,323 \text { Penerapan Disiplin }+ \\
\text { 0,302 Pemberian Kompensasi }+\varepsilon_{3} \ldots \ldots \ldots \ldots \ldots \text { (persamaan 3) }
\end{array}
$$

Dari persamaan 3, parameter pengaruh penerapan disiplin terhadap pemberian penghargaan adalah $\mathrm{p}_{5}$ sebesar 0,323 dan pengaruhnya adalah signifikan karena nilai signifikansinya lebih kecil dari 0,05 (sig=0,039), parameter pengaruh pemberian kompensasi terhadap pemberian penghargaan adalah $\mathrm{p}_{4}$ sebesar 0,302 dan pengaruhnya adalah signifikan karena nilai signifikansinya lebih kecil dari 0,05 (sig=0,042), sedangkan nilai $\mathrm{R}^{2}$ dari persamaan struktural ketiga melalui perhitungan SPSS adalah 0,299. Nilai $\varepsilon_{3}$ adalah akar dari 1 dikurangi $\mathrm{R}^{2}$ (Ghozali, 2009) sehingga nilainya sebesar :

$$
\varepsilon_{2}=\sqrt{\left(1-R^{2}\right)}=\sqrt{(1-0,299)}=0,8373
$$

\section{Pengaruh Langsung Penerapan Disiplin terhadap Kinerja Pegawai}

Pengaruh langsung penerapan disiplin terhadap kinerja pegawai didapatkan dari persamaan struktural 2 yaitu parameter $\mathrm{p}_{1}$ sebesar 0,209 dan pengaruhnya adalah signifikan. Sehingga hipotesis pertama yang menyatakan bahwa Penerapan disiplin berpengaruh langsung secara signifikan terhadap kinerja Pegawai BKKBN Provinsi Jawa Timur dapat diterima.

Pengaruh tidak langsung penerapan disiplin terhadap kinerja melalui pemberian kompensasi dan melalui pemberian penghargaan sebagai variabel intervening. 
Ada 3 buah pengaruh tidak langsung dari Penerapan Disiplin terhadap Kinerja Karyawan yaitu:

Pertama pengaruh tidak langsung melalui pemberian kompensasi yang nilainya adalah $\mathrm{p}_{2}$ dikalikan $\mathrm{p}_{3}$ sebesar $0,066 * 0,306=0,02$. Parameter $\mathrm{p}_{2}$ adalah signifikan dan parameter $\mathrm{p}_{2}$ juga signifikan. Sehingga hipotesis kedua yang menyatakan bahwa Penerapan disiplin berpengaruh tidak langsung melalui pemberian kompensasi secara signifikan terhadap kinerja Pegawai BKKBN Provinsi Jawa Timur dapat diterima.

Kedua pengaruh tidak langsung melalui pemberian kompensasi diteruskan melalui pemberian penghargaan yang nilainya adalah $\mathrm{p}_{2}$ dikalikan $\mathrm{p}_{4}$ dikalikan $\mathrm{p}_{6}$ sebesar 0,066 * $0,302 * 0,431=0,009$. Parameter $\mathrm{p}_{2}$ adalah signifikan, parameter $\mathrm{p}_{4}$ adalah signifikan dan parameter $\mathrm{p}_{6}$ juga signifikan. Sehingga hipotesis ketiga yang menyatakan bahwa Penerapan disiplin berpengaruh tidak langsung melalui pemberian penghargaan secara signifikan terhadap kinerja Pegawai BKKBN Provinsi Jawa Timur dapat diterima.

Ketiga adalah pengaruh tidak langsung melalui pemberian penghargaan yang nilainya adalah $\mathrm{p}_{5}$ dikalikan $\mathrm{p}_{6}$ sebesar $0,323 * 0,431=0,139$. Parameter $\mathrm{p}_{5}$ adalah signifikan, dan parameter $\mathrm{p}_{6}$ juga signifikan. Sehingga hipotesis ketiga yang menyatakan bahwa Penerapan disiplin berpengaruh tidak langsung melalui pemberian kompensasi dan melalui pemberian penghargaan terhadap kinerja Pegawai BKKBN Provinsi Jawa Timur dapat diterima.

Dalam pembahasan ini akan dibandingkan hasil penelitian ini dengan penelitian terdahulu sebagaimana berikut:

Lee \& Kamarul (2009) melakukan penelitian mengenai kinerja karyawan, kepuasan kerja dikaitkan dengan kepemimpinan dan komitmen organisasi di Malaysia. Data dikumpulkan melalui 238 mahasiswa paruh waktu program MBA University of Malaya, Kuala Lumpur. Hasil pengujian melalui "hierarchical multiple regression" menunjukkan bahwa komitmen organisasi tidak mempunyai hubungan yang signifikan terhadap kinerja karyawan dan kepuasan kerja. Hasil penelitian di BKKBN Jawa Timur ini tidak mendukung atau berlawanan dengan penelitian tersebut, namun salah satu dependen variabel penelitian yang digunakan adalah sama yakni kinerja karyawan, sedangkan independent adalah berbeda. Penelitian tersebut menggunakan variabel moderating kultur organisasi sedangkan pada penelitian ini menggunakan variabel intervening pemberian kompensasi dan pemberian penghargaan.

Steve at al., (2005) melakukan penelitian tentang sensitivitas budaya perusahaan, kualitas pelayanan pelanggan, perilaku konsumen di Amerika Serikat. Total responden adalah 230 pengunjung dari 27 hotel. Penghargaan merupakan salah satu komponen dari sensitivitas budaya perusahaan. Hasilnya adalah sensitivitas budaya perusahaan mempunyai hubungan yang signifikan terhadap kualitas pelayanan pelanggan dan perilaku konsumen. Dalam penelitian ini penghargaan yang merupakan salah satu komponen dari sensitivitas 
budaya perusahaan berperan sebagai variabel bebas. Hasil penelitian di BKKBN Jawa Timur ini, mempunyai persamaan dengan penelitian tersebut dalam hal penghargaan, istilah penghargaan utama (primary reward) adalah sama dengan pemberian kompensasi sedangkan istilah penghargaan kedua (secondary reward) adalah sama dengan pemberian penghargaan pada penelitian ini. Teknik statistik yang digunakan berbeda, pada penelitian tersebut menggunakan korelasi Pearson dan Analysis of Variance (ANOVA) sedangkan pada penelitian ini menggunakan analisis jalur (Path Analysis)

Darden et al., (1993) melakukan penelitian model kepuasan kerja dengan status karyawan sebagai variabel moderating di Amerika Serikat. Total sampel adalah 263 karayawan yang terdiri 144 karyawan penuh waktu dan 117 karyawan paruh waktu. Hasil penelitian yang terkait dengan kinerja karyawan adalah gaya partisipasi mempunyai pengaruh signifikan terhadap kinerja karyawan paruh waktu dan tidak berpengaruh signifikan terhadap kinerja karyawan penuh waktu. Hasil penelitian di BKKBN Jawa Timur ini mempunyai persamaan dengan penelitian tersebut yaitu kinerja sebagai variabel dependen, namun penelitian tersebut mengaitkan dengan gaya partisipasi dan status karyawan, sedang pada penelitian ini dikaitkan dengan penerapan disiplin, pemberian kompensasi dan pemberian penghargaan.

Darwish (1998) meneliti tentang kepuasan, keamanan kerja, komitmen organisasi dan kinerja karyawan pada lingkungan multikultural namun bukan negara barat di Arab Saudi. Kinerja karyawan diukur dengan pendekatan penilaian diri. Ada 5 hipotesis yang dikembangkan dalam penelitian ini, pada hipotesis kedua menyatakan bahwa terdapat hubungan positif signifikan antara kepuasan dalam keamanan kerja dengan kinerja karyawan. Hasilnya yang berkaitan dengan kinerja karyawan yaitu hipotesis kedua menunjukkan terdapat hubungan positif walaupun tidak sangat kuat antara kepuasan dalam keamanan kerja dengan kinerja karyawan. Hasil penelitian di BKKBN Jawa Timur ini mempunyai kesamaan pada kinerja karyawan sebagai fokus penelitian, sedangkan kepuasan dalam penelitian tersebut senada dengan pemberian kompensasi dan pemberian penghargaan dalam penelitian ini. Persamaan lain adalah pada teknik statistik yang digunakan yaitu menggunakan analisis regresi, sedangkan perbedaannya pada variabel bebasnya, pada penelitian tersebut mengaitkan dengan komitmen organisasi.

Darwish (2001) meneliti tentang komitmen organisasi, perilaku kepemimpinan, kepuasan kerja dan kinerja karyawan. Populasi adalah 50 buah organisasi pada 4 distrik utama di Arab Saudi. Responden adalah pekerja individu pada berbagai organisasi di Arab Saudi sebanyak 430 pekerja. Teknik statistik yang digunakan adalah regresi berganda dengan variabel moderating. Hasilnya pengujian hipotesis pertama dan hipotesis ketiga menunjukkan bahwa variabel kebangsaan mampu memoderasi hubungan antara perilaku kepemimpinan dan komitmen organisasi, kepuasan kerja dan kinerja karyawan, dan juga komitmen organisasi dan keduanya kepuasan kerja dan kinerja karyawan. Hasil pengujian hipotesis kedua menunjukkan bahwa variabel kebangsaan mampu memediasi hubungan 
antara gaya kepemimpinan dengan keduanya kepuasan kerja dan kinerja karyawan. Hasil penelitian di BKKBN Jawa Timur ini mempunyai kesamaan dalam hal kinerja karyawan, kepuasan kerja searah dengan pemberian kompensasi dan pemberian penghargaan pada penelitian ini. Sedangkan perbedaannya terletak pada variabel bebas yang lain yaitu perilaku kepemimpinan dan komitmen organisasi pada penelitian tersebut, untuk penelitian ini menggunakan penerapan disiplin.

\section{SIMPULAN DAN SARAN}

\section{Simpulan}

Berdasarkan masalah, tujuan, hipotesis dan hasil penelitian maka dapat disimpulkan :

1. Hipotesis yang menyatakan bahwa variabel penerapan disiplin mempunyai pengaruh langsung terhadap kinerja Pegawai BKKBN Provinsi Jawa Timur, dapat diterima pada $\alpha=0,05$. Hal tersebut ditunjukkan oleh hasil output SPSS menunjukkan tingkat signifikansi pada nilai beta sebesar 0,269 atau 26,9\%. Hal tersebut disebabkan karena faktor alat yang belum sempurna sebagai pengelolaan ketepatan waktu kerja pegawai, kurangnya efektifitas pemanfaatan waktu kerja, serta kurangnya teguran dari pimpinan untuk bawahan yang tidak mengikuti aturan jam kantor, serta kurang pengawasan kerja pegawai di BKKBN Provinsi Jawa Timur

2. Hipotesis yang menyatakan bahwa variabel penerapan disiplin mempunyai pengaruh tidak langsung melalui pemberian kompensasi secara signifikan terhadap kinerja Pegawai BKKBN Provinsi Jawa Timur, dapat diterima pada $\alpha=0.05$. Hal tersebut ditunjukkan oleh hasil output SPSS menunjukkan tingkat signifikansi pada nilai beta sebesar 0,306, sehingga pemberian kompensasi baik berupa materiil maupun immateriil untuk penerapan disiplin pegawai di BKKBN Provinsi Jawa Timur sangat diperlukan sebagai faktor motivasi bagi pegawai agar kinerja pegawai meningkat.

3. Hipotesis yang menyatakan bahwa variabel penerapan disiplin mempunyai pengaruh tidak langsung melalui pemberian penghargaan secara signifikan terhadap kinerja Pegawai BKKBN Provinsi Jawa Timur, dapat diterima pada $\alpha=0.05$. Hal tersebut ditunjukkan oleh hasil output SPSS menunjukkan tingkat signifikansi pada nilai beta sebesar 0,323 dan variabel pemberian penghargaan merupakan proporsi kedua setelah kompensasi. Hal tersebut mengindikasikan bahwa penghargaan merupakan salah satu faktor yang perlu diperhatikan dalam pengelolaan disiplin pegawai di BKKBN Provinsi Jawa Timur, sehingga di perlukan peningkatan pemberian penghargaan oleh pimpinan BKKBN provinsi jawa Timur berupa kenaikan pangkat, Promosi Jabatan dan penghargaan hasil kerja pegawai lainnya.

4. Hipotesis yang menyatakan bahwa variabel penerapan disiplin mempunyai pengaruh tidak langsung melalui pemberian kompensasi dan melalui pemberian penghargaan secara signifikan terhadap kinerja pegawai BKKBN Provinsi Jawa Timur, dapat diterima pada $\alpha=0.05$. Hal tersebut ditunjukkan oleh hasil output SPSS menunjukkan tingkat signifikansi pada nilai beta sebesar 0,032, Secara keseluruhan, kondisi 
pegawai BKKBN Provinsi Jawa Timur dalam meningkatkan kinerjanya secara langsung dipengaruhi oleh faktor disiplin pegawai. Sedangkan dalam peningkatan disiplin sesuai tata peraturan pegawai yang berlaku diperlukan faktor pendorong atau motivasi melalui pemberian kompensasi dan pemberian penghargaan.

\section{Saran}

Beberapa saran yang dapat dipertimbangkan atau dimanfaatkan berdasarkan simpulan di atas antara lain sebagai berikut:

Bagi BKKBN Provinsi Jawa Timur:

a. Penerapan Disiplin Pegawai Negeri Sipil agar dilaksanakan secara terus menerus dan konsisten yang diikuti dengan pembinaan pegawai, mensosialisasikan kewajiban dan larangan bagi Pegawai Negeri Sipil melalui buku saku yang diberikan kepada masing-masing Pegawai Negeri Sipil, serta menjatuhkan hukuman (punishment) secara tegas sesuai dengan ketentuan peraturan yang berlaku

b. Pemberian Kompensasi dan Penghargaan Kepada Pegawai Negeri Sipil agar disesuaikan dengan prestasi kerja, sehingga terdapat perbedaan antara Pegawai yang kinerjanya tinggi dengan pegawai yang kinerjanya rendah

c. Agar dapat melakukan pengukuran kinerja bagi Pegawai Negeri Sipil secara obyektif, maka diperlukan adanya standar kinerja bagi Pegawai Negeri Sipil yang lebih akurat, disamping itu pemberian nilai pada Daftar Penilaian Pelaksanaan Pekerjaan (DP3) yang meliputi 8 item penilaian yaitu kesetiaan, Prestasi Kerja, tanggung jawab, ketaatan, kejujuran, kerjasama, prakarsa dan kepemimpinan yang selama ini digunakan sebagai sarana penilaian terhadap Pegawai Negeri Sipil agar diperketat sesuai dengan kondisi yang sebenarnya dari Pegawai Negeri Sipil yang bersangkutan.

\section{DAFTAR PUSTAKA}

Babin, B. J., \& Boles, J. S. 1998. Employee behavior in a service environment: A model and test of potential differences between men and women. Journal of Marketing, $62,77-91$.

Beehr, T. A., Jex, S. M., Stacy, B. A., \& Murray, M. A. 2000. Work stressors and coworker support as predictors of individual strain and job performance. Journal of Organizational Behavior, 21, 391-405.

Boles, J. S., Johnston, M. W., \& Hair, J. F., Jr. 1997. Role stress, work-family conflict and emotional exhaustion: Inter-relationships and effects on some work-related consequences. Journal of Personal Selling \& Sales Management, 17, 17-28.

Brannick, M. T. 1995. Critical comments on applying covariance structure modeling. Journal of Organizational Behavior, 16, 201-213. 
Collins, C. J., Hanges, P. J., \& Locke, E. A. 2004. The relationship of achievement motivation to entrepreneurial behavior: A meta analysis. Human Performance, 17, 95-117.

Darden, William R; McKee, Daryl \& Hampton, Ronald. 1993. Salesperson employment status as a moderator in the job satisfaction model: A Frame of Reference Perspective. The Journal of Personal Selling \& Sales Management; Summer 1993; 13, 3; pp 1-15

Darwish A. Yousef. 1998. Satisfaction with job security as a predictor of organizational commitment and job performance in a multicultural environment. International Journal of Manpower. Bradford: 1998. Vol. 19, Iss. 3; pg. 184-193.

Darwish A. Yousef. 2001. Islamic work ethic - A moderator between organizational commitment and job satisfaction in a cross-cultural context. Personnel Review. Farnborough: 2001. Vol. 30, Iss. 2; pg. 152-166.

Dess, G. D., Lumpkin, G. T., \& Covin, J. G. 1997. Entrepreneurial strategy making and firm performance: Tests of contingency and configurational models. Strategic Management Journal, 18, 677-695.

Floyd, S. W., \& Lane, P. J. 2000. Strategizing throughout the organization: Managing role conflict in strategic renewal. Academy of Management Review, 25, 154-177.

Ghozali, Imam, M. 2009. Aplikasi Analisis Multivariate dengan program SPSS. Edisi IV, Badan Penerbit Universitas Diponegoro, Semarang.

Handoko. 2001. Manajemen Personalia Dan Sumber Daya Manusia, Yogyakarta BPFE.

Heidjrachman dan Husnan Suad. 2002. Manajemen Personalia, Yogyakarta ; BPFE Yogyakarta.

Irianto, J. 2001. Tema-tema Pokok Manajemen Sumber Daya Manusia, Surabaya, Insan Cendekia.

Johnson, B. 1990. Toward a multidimensional model of entrepreneurship: The case of achievement motivation and the entrepreneur. Entrepreneurship: Theory \& Practice, 14, 39-54.

Lee Huey Yiing \& Kamarul Zaman Bin Ahmad. 2009. The moderating effects of organizational culture on the relationships between leadership behaviour and organizational commitment and between organizational commitment and job 
satisfaction and performance. Leadership \& Organization Development Journal Vol. 30 No. 1, 2009, pp. 53-86.

Lysonski, S., \& Andrews, G. 1990. Effects of moderating variables on product managers behavior. Psychological Reports, 66, 295-306.

Mackeana, E. \& Nic Beech. 1995. Manajemen Sumber Daya Manusia, Yogyakarta. Andi \& Pearson Education Asia Pte.Ltd.

Mangkunegaran, Anwar Prabu. 2001. Manajemen Sumber Daya Manusia Perusahaan, cetakan ketiga, PT Remaja Rosdakarya, Bandung.

O’Driscoll, M. P., \& Beehr, T. A. 1994. Supervisor behaviors, role stressors and uncertainty as predictors of personal outcomes for subordinates. Journal of Organizational Behavior, 15, 141-155.

Ranupandojo, H, \& Husnan, S. 2002. Manajemen Personalia, Yogyakarta, BPFE.

Rao, T.V. 1998. Performance Appraisal Theory dan Practice, Terjemahan Mulyana, PT, Pustaka Binaman Pressindo, Jakarta.

Sedarmayanti. 2001. Sumber Daya Manusia dan Produktivitas Kerja, Bandung, Mandar Maju

Simamora, Henry. 2003. Manajemen Sumber Daya Manusia, Yogyakarta, STIE YKPN.

Steve Sizoo; Richard Plank; Wilfried Iskat; Hendrick Serrie. 2005. The effect of intercultural sensitivity on employee performance in cross-cultural service encounters. The Journal of Services Marketing; 2005; 19, 4; pg. 245 - 256.

Sugiono. 2007. Metode Penelitian Bisnis. Penerbit: CV Alfabeta Bandung.

Sulistiyani, A T \& Rosidah. 2003. Manajemen Sumber Daya Manusia, Konsep, Teori dan Pengembangan dalam Konteks Organisasi Publik, Yogyakarta, Graha Ilmu.

Wibowo, Arief. 2003. Materi Pelatihan Struktural Equation Modelling (Pemodalan Persamaan Struktural). Lembaga Penelitian Universitas Airlangga. 